\title{
Origins and bioavailability of dissolved organic matter in groundwater
}

\author{
Yuan Shen • Francis H. Chapelle • \\ Eric W. Strom • Ronald Benner
}

Received: 28 January 2014/Accepted: 23 August 2014/Published online: 5 September 2014

(C) The Author(s) 2014. This article is published with open access at Springerlink.com

\begin{abstract}
Dissolved organic matter (DOM) in groundwater influences water quality and fuels microbial metabolism, but its origins, bioavailability and chemical composition are poorly understood. The origins and concentrations of dissolved organic carbon (DOC) and bioavailable DOM were monitored during a long-term (2-year) study of groundwater in a fractured-rock aquifer in the Carolina slate belt. Surface precipitation was significantly correlated with groundwater concentrations of DOC, bioavailable DOM and chromophoric DOM, indicating strong hydrological connections between surface and ground waters. The physicochemical and biological processes shaping the concentrations and compositions of DOM during its passage through the soil column to the saturated zone are conceptualized in the regional chromatography model. The model provides a framework for linking hydrology with the processes
\end{abstract}

Responsible Editor: J. M. Melack.

Y. Shen $(\bowtie) \cdot$ R. Benner

Marine Science Program, University of South Carolina, Columbia, SC 29208, USA

e-mail: shen2@email.sc.edu

F. H. Chapelle · E. W. Strom

U.S. Geological Survey, South Carolina Water Science

Center, Columbia, SC 29210, USA

R. Benner

Department of Biological Sciences, University of South

Carolina, Columbia, SC 29208, USA affecting the transformation, remineralization and microbial production of DOM during passage through the soil column. Lignin-derived phenols were relatively depleted in groundwater DOM indicating substantial removal in the unsaturated zone, and optical properties of chromophoric DOM indicated lower molecular weight DOM in groundwater relative to surface water. The prevalence of glycine, $\gamma$ aminobutyric acid, and D-enantiomers of amino acids indicated the DOM was highly diagenetically altered. Bioassay experiments were used to establish DOCnormalized yields of amino acids as molecular indicators of DOM bioavailability in groundwater. A relatively small fraction $(8 \pm 4 \%)$ of DOC in groundwater was bioavailable. The relatively high yields of specific D-enantiomers of amino acids indicated a substantial fraction (15-34 \%) of groundwater DOC was of bacterial origin.

Keywords Groundwater - Dissolved organic matter - Amino acids · Lignin phenols - CDOM . Bioavailability $\cdot$ Regional chromatography model

\section{Introduction}

Groundwater stores the majority of liquid fresh water on Earth and is a major source of water for human consumption and agriculture. Groundwater quality is a key environmental issue and is often assessed by 
monitoring dissolved organic matter (DOM) through measurements of dissolved organic carbon (DOC) concentrations (Leenheer et al. 1974; Barcelona 1984). Concentrations of DOC can reflect the likelihood of contamination by synthetic organic compounds (Barcelona 1984). Humic and fulvic acids in DOM affect the solubility of organic pollutants in groundwater and can contribute to the long-range transport of harmful chemicals (Chiou et al. 1986). High DOC loading in groundwater can also lead to production of carcinogenic disinfection byproducts during drinking water treatment (Singer 1994; Chomycia et al. 2008). Groundwater DOM also serves as a source of carbon and energy for heterotrophic metabolism and drives the bioremediation of many contaminants (Hendriksen et al. 1992; McCarty 1997; Baker et al. 2000).

Early studies of groundwater emphasized measuring the concentrations of DOC, so little is known about the origin, composition, and bioreactivity of groundwater DOM (Leenheer et al. 1974; Thurman 1985). More recent studies indicate surface plant litter and soil are important sources of DOM in groundwater (Baker et al. 2000; Kalbitz et al. 2000). Surface precipitation drives the transport of DOM through the soil column to the saturated zone. During infiltration, selective interactions between DOM and soil minerals occur and result in differential retention of certain DOM constituents within the soils. This concept has been described in the regional chromatography model in river systems (Hedges et al. 1986, 1994) and is also applicable to groundwater environments (Jardine et al. 1989; Qualls and Haines 1992; Kaiser et al. 2004). The chemical composition and bioavailability of DOM, which are key factors affecting water quality and diagenetic processes in groundwater, are altered during its transport through the soil column. The bioavailability of DOM is tightly linked to its origins and its utilization by microorganisms and is not readily reflected in the concentrations of DOC (Benner 2003; Chapelle et al. 2009).

Bioavailability of DOM is commonly measured using bioassay experiments (e.g., Sondergaard and Middelboe 1995), which are time consuming to conduct and therefore limited in spatial and temporal coverage. Molecular analyses of specific biochemical components of DOM can provide qualitative and quantitative insights about the bioavailability and diagenetic alteration of DOM without conducting bioassay experiments (Benner 2003; Davis and Benner 2007; Shen et al. 2012a). Amino acids are bioreactive components of DOM and have been used as molecular indicators of bioavailable DOM in marine environments (Benner 2003; Davis et al. 2009) and have been applied recently to groundwater (Chapelle et al. 2009). The composition of hydrolysable amino acids in DOM can be informative for revealing the extent of diagenetic processing of DOM. For instance, mole fractions of glycine, non-protein amino acids ( $\beta$-alanine and $\gamma$-aminobutyric acid), and D-enantiomers of amino acids (D-AA) increase with advancing diagenetic alteration of DOM (Jørgensen et al. 1999; Davis and Benner 2005; Kaiser and Benner 2009). Likewise, some biomolecules have specific sources and can be excellent tracers of the origins of DOM. Lignin is a structural biopolymer unique to vascular plants, making lignin phenols biomarkers of plant-derived DOM (Meyers-Schulte and Hedges 1986; Opsahl and Benner 1997; Benner et al. 2005). The combined forms of D-aspartic and glutamic acids, D-serine, and D-alanine occur in a variety of macromolecules that are only found in bacteria, thereby serving as useful biomarkers for tracing bacterialderived DOM (McCarthy et al. 1998; Kaiser and Benner 2008).

Several studies have examined the bioavailability of DOM in groundwater using amino acids and other bioreactive compounds (e.g., carbohydrates) (Routh et al. 2001; Chapelle et al. 2009; Peter et al. 2012). These studies have provided a snapshot of the relatively low bioavailability of DOM in groundwater. Nevertheless, the temporal variability of DOM bioavailability and its connection with surface DOM are poorly understood. Microbes, especially heterotrophic bacteria, play an important role in transforming bioavailable DOM to refractory DOM (Ogawa et al. 2001). The bacterial contributions to groundwater DOM, however, have not been investigated.

In this study, long-term (2-year) variations of DOC concentration, origin, composition and bioavailability were monitored monthly in a fractured-rock aquifer in the Carolina Slate Belt overlain by weathered bedrock located in South Carolina. The Carolina Slate Belt consists of sedimentary rocks of Cambrian age $(\sim 550$ million years) that have been subjected to several cycles of high- to low-temperature metamorphosis (Hibbard et al. 2002). These metamorphic events transformed the sediments into lithified phyllites, 
slates, mica schists, and quartzites intruded with metaigneous rocks. Importantly, these metamorphic events effectively coalified the organic carbon originally buried with the sediments, presumably rendering it largely non-biodegradable. Thus, DOM present in the groundwater in this region is predominantly derived from surface litter and soil rather than from the fractured-rock aquifer matrix.

\section{Materials and methods}

\section{Sample collection}

Groundwater samples were collected from a U.S. Geological Survey (USGS) well (site number: $340837081173800-R I C-748 ; 34^{\circ} 08^{\prime} 37^{\prime \prime} \mathrm{N}, 81^{\circ} 17^{\prime} 38^{\prime \prime} \mathrm{W}$ ) located in a forested area of Richland County, South Carolina. The well is part of the USGS climate response network because it reflects climatic variability (e.g., seasonal changes in recharge and subsequent water levels), and not human influences (Cunningham et al. 2007). The well was drilled to a depth of $76 \mathrm{~m}$ through a soil horizon, weathered bedrock, $(0-12 \mathrm{~m})$ and fractured rock (12-76 m), with an open hole below the casing depth of $12 \mathrm{~m}$. The average water temperature in the well was $17 \pm 1{ }^{\circ} \mathrm{C}$ and the water level varied from 2.3 to $6.7 \mathrm{~m}$ below the land surface during the study period from July 2010 to August 2012. The well (domestic) was shut off at least $8 \mathrm{~h}$ prior to sampling. Water samples were pumped from a depth of $9 \mathrm{~m}$ with a peristaltic pump at a flow rate of about $500 \mathrm{~mL} \mathrm{~min}^{-1}$. Water pressure between the fractures recorded at 33, 51, and $66 \mathrm{~m}$ was likely different due to differences in depth, and convection currents due to temperature differentials would occur without recent pumping (Vroblesky et al. 2006), resulting in water mixing within the well. The collected samples are therefore thought to integrate the optical and biochemical characteristics of water and DOM throughout the saturated zone. Groundwater samples were collected approximately at monthly intervals $(n=24)$. Surface water samples were collected from small creeks in the vicinity $(<1 \mathrm{~km})$ of the well $(n=4)$. Water samples were collected in clean amber glass bottles, stored in the dark at $4{ }^{\circ} \mathrm{C}$, and processed in the laboratory within $72 \mathrm{~h}$ of collection. Samples were filtered through pre-cleaned $0.2-\mu \mathrm{m}$ pore-size membrane filters $\left(\right.$ Supor $^{\mathbb{B}}-200$, Life Sciences) prior to optical and chemical analyses.

\section{Bioassay experiments}

Two different types of bioassay experiments were used to measure (1) the microbial utilization and bioavailability of DOM, and (2) the microbial production of DOM. In the DOM bioavailability experiments, ground and surface waters were filtered through pre-combusted filters $(0.7 \mu \mathrm{m}$ pore-size $\mathrm{GF} / \mathrm{F}$, Whatman) to remove most particles and eukaryotes while leaving the prokaryotic community largely intact. Filtered water samples were incubated in duplicates $(500 \mathrm{~mL})$ in glass bottles and kept in the dark at room temperature $\left(23-26{ }^{\circ} \mathrm{C}\right)$. Concentrations of DOC and amino acids were monitored on days $0,7,14,21,28,35$, and 42 . In the bacterial DOM production experiments, a groundwater inoculum was prepared by filtering a water sample $(0.7 \mu \mathrm{m}$ pore-size $\mathrm{GF} / \mathrm{F}$ ), and a 1:50 dilution of the filtered water was added as an inoculum to a mineral media with an adjusted $\mathrm{pH}$ $(\sim 6.9)$ similar to that in the groundwater inoculum (Porcella et al. 1980). Glucose $\left(250 \mu \mathrm{mol} \mathrm{C} \mathrm{L}{ }^{-1}\right)$ was added as the sole $\mathrm{C}$ and energy source, and sodium nitrate $\left(53 \mu \mathrm{mol} \mathrm{L}^{-1}\right)$ and monopotassium phosphate $\left(2.6 \mu \mathrm{mol} \mathrm{L}{ }^{-1}\right)$ were added as $\mathrm{N}$ and $\mathrm{P}$ sources. Three replicates $(500 \mathrm{~mL}$ each) were incubated in the dark at room temperature $\left(23-26^{\circ} \mathrm{C}\right)$. Subsamples for DOC and amino acids were collected on days $0,2,4,9,14,21$, and 28. In both experiments, water samples were filtered through pre-cleaned $0.2-\mu \mathrm{m}$ pore-size membrane filters (Supor $^{\circledR}-200$, Life Sciences) before analysis.

\section{Chemical and optical analyses}

Concentrations of DOC were measured using hightemperature combustion via a Shimadzu TOC-V analyzer (Benner and Strom 1993). Milli-Q UV-Plus water was injected every 6th sample as a blank and the blanks were negligible. Absorbance spectra (250-800 nm) of water samples were determined using a dual-beam Shimadzu 1601 spectrophotometer and $10-\mathrm{cm}$ quartz cuvettes. For highly absorbing surface water samples, 1-cm quartz cuvettes were used. Absorbances corrected for blank (the average absorbance between 690 and $700 \mathrm{~nm}$ ) were converted to Napierian absorption coefficients: $a_{\lambda}\left(\mathrm{m}^{-1}\right)=2.303 A_{\lambda} / r$, where $A_{\lambda}$ is the absorbance measured across pathlength $r$ at a wavelength of $\lambda$. Spectral slope coefficients, $S$, were calculated using a linear fit of log-linearized $a_{\lambda}: a_{\lambda}=a_{\lambda 0} \exp \left[-S\left(\lambda-\lambda_{0}\right)\right]$, where $a_{\lambda}$ and $a_{\lambda 0}$ are absorption coefficients at wavelengths $\lambda$ and $\lambda_{0}\left(\lambda>\lambda_{0}\right)$. In this study, $S$ in the 275-295 
and 350-400 $\mathrm{nm}$ spectral ranges were determined and are reported as $S_{275-295}$ and $S_{350-400}$ with units of $\mathrm{nm}^{-1}$. The slope ratio, $S_{\mathrm{R}}$, was calculated as the ratio of $S_{275-295}$ to $S_{350-400}$. Specific UV absorbance at $254 \mathrm{~nm}$ (SUVA ${ }_{254}$ ) was determined by dividing the UV absorbance at $254 \mathrm{~nm}$ by the DOC concentration and is reported in units of $\mathrm{L} \mathrm{mgC}^{-1} \mathrm{~m}^{-1}$ (Weishaar et al. 2003).

The D- and L-enantiomers of amino acids were analyzed using an Agilent 1200 high-performance liquid chromatography system equipped with a fluorescence detector. Water samples were dried under nitrogen gas and subjected to vapor-phase hydrolysis with $6 \mathrm{~mol} \mathrm{~L}^{-1}$ hydrochloric acid at $150{ }^{\circ} \mathrm{C}$ for $32.5 \mathrm{~min}$ in a CEM Mars 5000 microwave (Kaiser and Benner 2005). Free amino acids were analyzed in a subset of samples that were not hydrolyzed. Amino-acid enantiomers were derivatized with $o$-phthaldialdehyde and $\mathrm{N}$-isobutyryl-L-cysteine and were separated on a Poroshell 120 EC-C18 $(4.6 \times 100 \mathrm{~mm}, 2.7 \mu \mathrm{m}$ particles $)$ column. Acid-catalyzed racemization of enantiomers during hydrolysis was corrected according to Kaiser and Benner (2005). Eighteen amino acids were included in the analysis: asparagine + aspartic acid (Asx), glutamine + glutamic acid (Glx), serine (Ser), histidine (His), glycine (Gly), threonine (Thr), $\beta$-alanine ( $\beta$-Ala), arginine (Arg), alanine (Ala), $\gamma$-aminobutyric acid $(\gamma$-Aba), tyrosine (Tyr), valine (Val), phenylalanine (Phe), isoleucine (Ile), leucine (Leu), and lysine (Lys). D-enantiomers of Asx, Glx, Ser, and Ala were reported in this study. DOCnormalized yields of total dissolved amino acids (TDAA) were calculated as: TDAA $(\% D O C)=$ $\frac{\text { carbon in TDAA }}{D O C} \times 100$, where the denominator and numerator represent concentrations of total DOC and the DOC comprised by TDAA, respectively. The two non-protein amino acids ( $\beta$-Ala and $\gamma$-Aba) are thought to be by-products of diagenesis (Cowie and Hedges 1994) and were not included in the yield calculation.

Lignin phenols were analyzed in four surface and groundwater samples to trace plant-derived molecules in the DOM. Water samples (1-4 L) were filtered through Nuclepore filters $(0.2-\mu \mathrm{m}$ pore size) and were acidified to $\mathrm{pH} 2.5$ with $5 \mathrm{~mol} \mathrm{~L}^{-1}$ sulfuric acid. Acidified samples were extracted using C-18 cartridges (Varian MegaBond Elut) at a flow rate of $50 \mathrm{~mL} \mathrm{~min}^{-1}$ (Louchouarn et al. 2000). Dissolved lignin was eluted in $30 \mathrm{~mL}$ of methanol and analyzed using the $\mathrm{CuO}$ oxidation method as described by Kaiser and Benner (2012). Lignin oxidation products were determined as trimethylsilyl derivatives and quantified using an Agilent 7890 gas chromatograph with a DB5-MS capillary column and an Agilent 5975 mass selective detector. Eight lignin phenols were measured: vanillin (VAL), acetovanillone (VON), vanillic acids (VAD), syringaldehyde (SAL), acetosyringone (SON), syringic acid (SAD), $p$-coumaric acid (CAD), and ferulic acid (FAD). The sum of six lignin phenols (VAL, VON, VAD, SAL, $\mathrm{SON}$, and SAD) are reported in this study as total dissolved lignin phenols $\left(\mathrm{TDLP}_{6}\right)$. DOC-normalized yields of $\mathrm{TDLP}_{6}$ were calculated as the percentage of DOC measured in these six lignin phenols.

\section{Bacterial contributions to DOC}

Bacterial contributions to groundwater DOC were estimated using D-amino acids as tracers of bacterial carbon (Kaiser and Benner 2008). The fraction of bacteriallyderived DOC was calculated as: Bacterial DOC $(\%)=$ $\frac{D-A A_{D O M}}{D-A A_{\text {bacterial DOM }}} \times 100$, where $\mathrm{D}-\mathrm{AA} \mathrm{DOM}_{\mathrm{DOM}}$ and D-AA $\mathrm{A}_{\text {bacte- }}$ rial DOM are the DOC-normalized yields of individual D-amino acids (Asx, Glx, Ser, Ala) in groundwater DOM and freshly-produced (4-28 days) bacterial DOM, respectively.

\section{Statistical analyses}

The significance of correlations between variables was determined using a Pearson Correlation (two-tailed, $a=0.05$ ). For variables that were not normally distributed, the Spearman's rho test was used (twotailed, $a=0.05$ ). Normality of variables was tested using a Kolmogorov-Smimov (K-S) test (two-tailed, $a=0.05)$. Statistical differences were assessed using the Mann-Whitney $U$ test (two-tailed, $a=0.05$ ) because this test does not require assumptions of normality and equal group size. All the statistical analyses were performed using SPSS 20.0 (IBM Statistical Package for the Social Sciences Inc.).

\section{Results}

Concentrations of DOM in ground and surface waters

The concentrations of DOC in groundwater displayed moderate temporal variations and ranged from 69 to 
Fig. 1 Temporal variations in a concentrations of dissolved organic carbon (DOC), b CDOM absorption coefficients at $254 \mathrm{~nm}$ $\left(a_{254}\right)$, c concentrations of total dissolved amino acids (TDAA), and d concentrations of $\mathrm{D}$ enantiomers of amino acids (D-AA) in groundwater
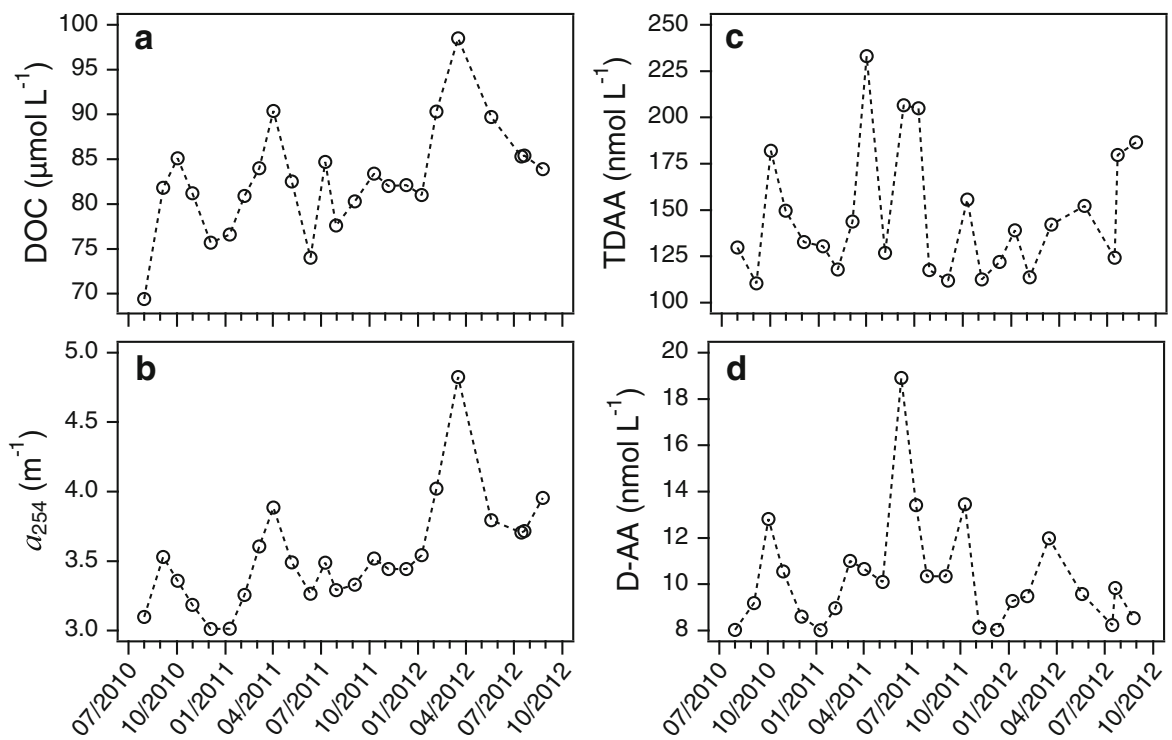

Date

$99 \mu \mathrm{mol} \mathrm{L}{ }^{-1}$, which were $\sim 10$ times lower than those (322-1,538 $\mu \mathrm{mol} \mathrm{L}^{-1}$ ) in surface water (Fig. 1a; Table 1). The absorption coefficient, $a_{254}$, varied from 3.01 to $4.82 \mathrm{~m}^{-1}$ in groundwater, and had a maximal value in March 2012 when the highest concentrations of DOC were measured (Fig. 1b; Table 2). Temporal patterns of $a_{254}$ and DOC concentrations were similar, and a significant relationship was found between these variables $\quad\left(a_{254}=0.058 \times \mathrm{DOC}-1.24, \quad R^{2}=0.785\right.$, $p<0.001, n=24)$. Concentrations of TDAA in groundwater ranged from 111 to $234 \mathrm{nmol} \mathrm{L}^{-1}$, which were $\sim 25$-fold lower than those $\left(1,668-5,880 \mathrm{nmol} \mathrm{L}^{-1}\right)$ in surface waters (Table 1). Compared with DOC concentrations, TDAA concentrations were more variable and displayed a different temporal pattern (Fig. 1a, c). Combined forms of D-amino acids (D-AA) were measured in groundwater and the total concentrations of D-AA ranged from 8.0 to $19 \mathrm{nmol} \mathrm{L}^{-1}$ (Fig. 1d; Table 1).

Bioavailable DOM in ground and surface waters

Concentrations of DOC decreased from 95 to $81 \mu \mathrm{mol} \mathrm{L}{ }^{-1}$ in groundwater and from 608 to $429 \mu \mathrm{mol} \mathrm{L}^{-1}$ in surface water during 35-days of incubation (Fig. 2) in the unamended bioassay experiments. No change and a minor decline $(\sim 2 \%)$ in DOC concentrations were observed after 35-days in ground and surface waters, respectively. Bioavailable DOC (BDOC) accounted for 14 and $29 \%$ of the DOC in ground and surface waters, respectively. A larger decrease in TDAA concentrations was observed, with 54 and $68 \%$ utilized during 35-days in ground and surface waters, respectively (Fig. 2).

The average DOC-normalized yield of TDAA was significantly lower in groundwater $(0.68 \pm 0.17 \%$ DOC, $n=24)$ than in surface water $(2.25 \pm 1.57 \%$ DOC, $n=4)(p<0.002$; Table 1). During 35-days of incubation, TDAA yields declined from 1.02 to $0.43 \%$ of DOC in groundwater (Fig. 3a). In surface water, TDAA yields followed a similar pattern (from 2.13 to $0.81 \%$ DOC) but were higher at the end of the experiment (Fig. 3a).

The BDOC at each time point $\left(t_{\mathrm{i}}\right)$ was calculated as the difference in DOC concentrations between $t_{\mathrm{i}}$ and day 35 in the groundwater experiment. A significant positive relationship was observed between percentages of BDOC and TDAA yields $\left(R^{2}=0.975\right.$, $p<0.001$; Fig. 3b). Based on these experimental results, we assumed that all BDOC was utilized when TDAA yields were below $0.43 \%$ DOC. TDAA yields varied from 1.02 to $0.43 \%$ DOC during the experiments, and the yields in all but one of the field samples fell within this range (Table 1).

A 2-year time series of BDOC in groundwater samples was derived from TDAA yields. The calculated percentages of BDOC exhibited large seasonal variations and ranged from 1 to $17 \%$ (avg. $8 \pm 4 \%$; Fig. 4). The influence of precipitation on the relative abundance 


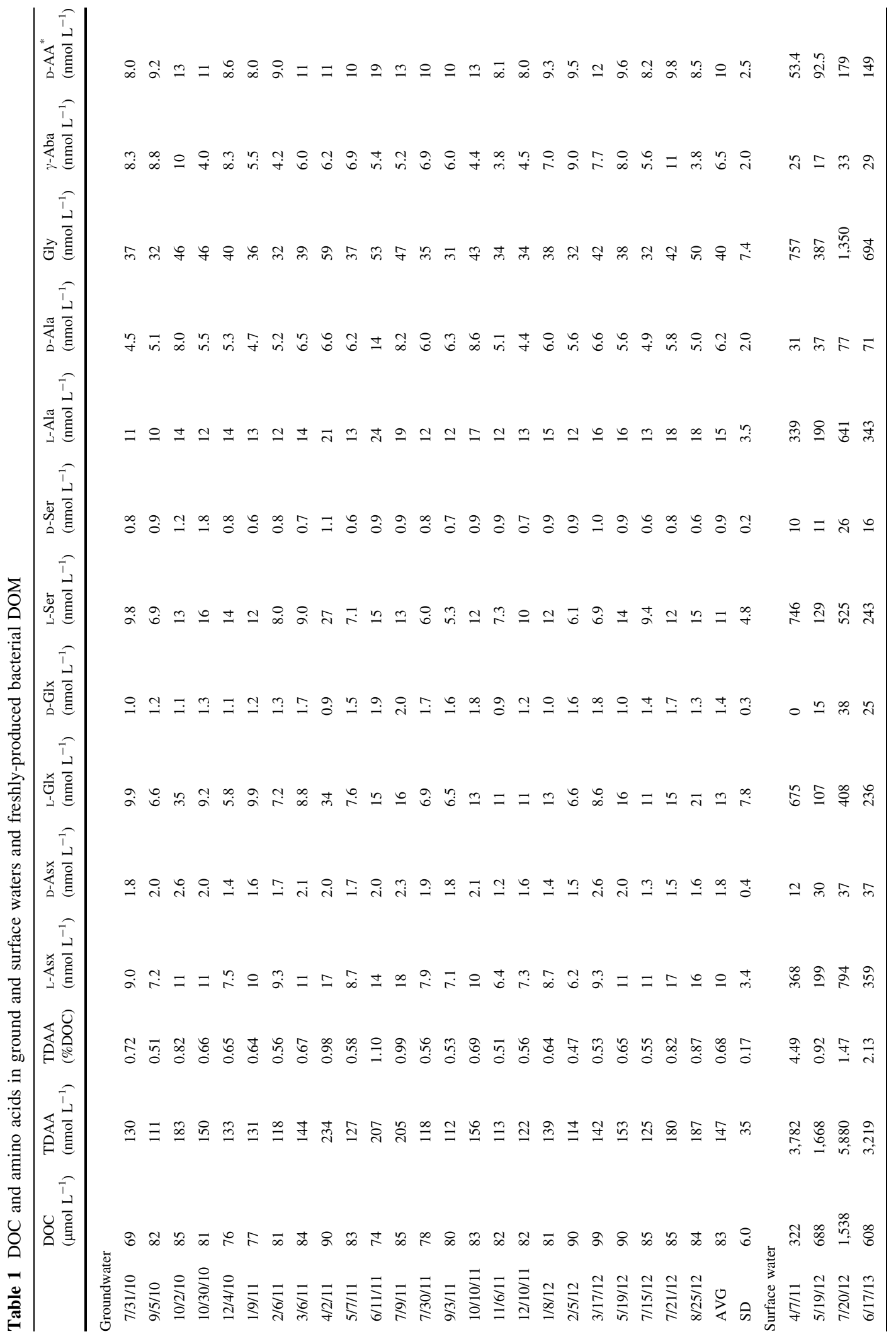


of BDOC in groundwater was investigated by correlating the integrated surface precipitation during the previous 1-60 days with the percentage of BDOC in groundwater. The most significant correlation was observed between the percentage of BDOC and the previous 10-days of precipitation $(r=0.735, p<0.001$; Table 3; Fig. 4). The correlation was weaker when longer preceding time periods of precipitation were considered (e.g., 27-days; $r=0.419, p<0.05$; Table 3). In general, high percentages of BDOC occurred immediately after precipitation events and low percentages of BDOC occurred during periods lacking precipitation (Fig. 4). One exception occurred in August 2012, when precipitation was very high $(20.45 \mathrm{~cm}$; data not shown) and BDOC did not increase proportionally. Transpiration by vegetation is very high during the summer, thereby reducing groundwater recharge. Thus, high percentages of BDOC appear to correlate with active recharge to the aquifer, whereas low percentages of BDOC correlate with a lack of recharge.

DOM diagenesis in ground and surface waters

Three amino acid-based indicators of DOM diagenesis were developed from the unamended incubation experiments (Fig. 5). Mole percentages of glycine increased gradually from 22 to $33 \%$ throughout the incubation period in surface water (Fig. 5a). In comparison, mole percentages of glycine in groundwater started with a lower initial value (16\%) but increased rapidly and were similar to values (30-31\%) in surface water (Fig. 5a). Mole percentages of $\gamma$-aminobutyric acid ( $\gamma$-Aba) were similar in the initial ground and surface waters and increased dramatically from 1.2 to $5.5 \%$ in groundwater while only a minor increase (from 0.84 to $1.4 \%$ ) was observed in surface water (Fig. 5b). Mole percentages of D-AA in groundwater increased threefold after 14-days and reached a plateau ( $23 \%$ ) after 28-days (Fig. 5c). In surface water, D-AA increased to $19 \%$ on day 14 and then remained constant (Fig. 5c). Average mole percentages of glycine, $\gamma$-Aba, and D-AA were all significantly higher in groundwater than in surface water $(p<0.005$; Fig. 5d, e, f). Differences were most pronounced in $\gamma$ Aba, which was sixfold higher in groundwater, followed by D-AA and glycine (Fig. 5d, e, f).

Likewise, mole percentages of $\gamma$-Aba showed the most pronounced temporal variations in groundwater, followed by D-AA and glycine (Fig. 6). Significant negative correlations were observed between 
Table 2 Optical properties of DOM in ground and surface waters

\begin{tabular}{|c|c|c|c|c|c|c|c|}
\hline & $\begin{array}{l}a_{254} \\
\left(\mathrm{~m}^{-1}\right)\end{array}$ & $\begin{array}{l}a_{280} \\
\left(\mathrm{~m}^{-1}\right)\end{array}$ & $\begin{array}{l}a_{350} \\
\left(\mathrm{~m}^{-1}\right)\end{array}$ & $\begin{array}{l}\mathrm{SUVA}_{254} \\
\left(\mathrm{~L} \mathrm{mgC}^{-1} \mathrm{~m}^{-1}\right)\end{array}$ & $\begin{array}{l}S_{275-295} \\
\left(\mathrm{~nm}^{-1}\right)\end{array}$ & $\begin{array}{l}S_{350-400} \\
\left(\mathrm{~nm}^{-1}\right)\end{array}$ & $S_{\mathrm{R}}$ \\
\hline \multicolumn{8}{|c|}{ Groundwater } \\
\hline $7 / 31 / 10$ & 3.10 & 1.97 & 0.415 & 1.62 & 0.0188 & 0.0258 & 0.731 \\
\hline $9 / 5 / 10$ & 3.53 & 2.19 & 0.445 & 1.56 & 0.0199 & 0.0255 & 0.781 \\
\hline $10 / 2 / 10$ & 3.36 & 2.18 & 0.402 & 1.43 & 0.0202 & 0.0257 & 0.787 \\
\hline $10 / 30 / 10$ & 3.18 & 2.01 & 0.398 & 1.42 & 0.0203 & 0.0264 & 0.771 \\
\hline $12 / 4 / 10$ & 3.01 & 1.89 & 0.365 & 1.44 & 0.0199 & 0.0272 & 0.731 \\
\hline $1 / 9 / 11$ & 3.01 & 1.89 & 0.356 & 1.42 & 0.0204 & 0.0277 & 0.738 \\
\hline $2 / 6 / 11$ & 3.26 & 2.02 & 0.380 & 1.46 & 0.0207 & 0.0265 & 0.778 \\
\hline $3 / 6 / 11$ & 3.61 & 2.27 & 0.431 & 1.55 & 0.0205 & 0.0276 & 0.743 \\
\hline $4 / 2 / 11$ & 3.89 & 2.46 & 0.471 & 1.55 & 0.0201 & 0.0270 & 0.744 \\
\hline $5 / 7 / 11$ & 3.49 & 2.17 & 0.417 & 1.53 & 0.0206 & 0.0274 & 0.753 \\
\hline $6 / 11 / 11$ & 3.26 & 2.03 & 0.388 & 1.60 & 0.0209 & 0.0285 & 0.732 \\
\hline $7 / 9 / 11$ & 3.49 & 2.18 & 0.430 & 1.49 & 0.0205 & 0.0267 & 0.767 \\
\hline $7 / 30 / 11$ & 3.29 & 2.03 & 0.389 & 1.53 & 0.0209 & 0.0268 & 0.777 \\
\hline $9 / 3 / 11$ & 3.33 & 2.06 & 0.382 & 1.50 & 0.0217 & 0.0277 & 0.783 \\
\hline $10 / 10 / 11$ & 3.52 & 2.11 & 0.396 & 1.53 & 0.0223 & 0.0268 & 0.832 \\
\hline $11 / 6 / 11$ & 3.44 & 2.11 & 0.395 & 1.52 & 0.0220 & 0.0265 & 0.833 \\
\hline $12 / 10 / 11$ & 3.44 & 2.12 & 0.397 & 1.52 & 0.0220 & 0.0259 & 0.849 \\
\hline $1 / 8 / 12$ & 3.54 & 2.19 & 0.404 & 1.58 & 0.0224 & 0.0278 & 0.806 \\
\hline $2 / 5 / 12$ & 4.02 & 2.46 & 0.448 & 1.61 & 0.0226 & 0.0279 & 0.808 \\
\hline $3 / 17 / 12$ & 4.82 & 2.99 & 0.564 & 1.77 & 0.0217 & 0.0262 & 0.827 \\
\hline $5 / 19 / 12$ & 3.80 & 2.35 & 0.434 & 1.53 & 0.0219 & 0.0269 & 0.816 \\
\hline $7 / 15 / 12$ & 3.71 & 2.25 & 0.424 & 1.57 & 0.0226 & 0.0260 & 0.869 \\
\hline $7 / 21 / 12$ & 3.72 & 2.27 & 0.402 & 1.57 & 0.0227 & 0.0270 & 0.843 \\
\hline $8 / 25 / 12$ & 3.95 & 2.41 & 0.438 & 1.71 & 0.0227 & 0.0275 & 0.825 \\
\hline AVG & 3.53 & 2.19 & 0.415 & 1.54 & 0.0212 & 0.0268 & 0.788 \\
\hline SD & 0.39 & 0.23 & 0.042 & 0.09 & 0.0011 & 0.0008 & 0.042 \\
\hline \multicolumn{8}{|c|}{ Surface water } \\
\hline $4 / 7 / 11$ & 20.7 & 14.9 & 4.42 & 2.33 & 0.0163 & 0.0200 & 0.817 \\
\hline $5 / 19 / 12$ & 60.8 & 43.0 & 12.5 & 3.19 & 0.0160 & 0.0204 & 0.783 \\
\hline $7 / 20 / 12$ & 129 & 97.1 & 32.4 & 3.05 & 0.0141 & 0.0186 & 0.754 \\
\hline $6 / 17 / 13$ & 49.9 & 37.3 & 12.0 & 2.97 & 0.0150 & 0.0196 & 0.763 \\
\hline AVG & 65.2 & 48.1 & 15.3 & 2.88 & 0.0153 & 0.0197 & 0.779 \\
\hline SD & 46.0 & 34.9 & 11.9 & 0.38 & 0.0010 & 0.0008 & 0.028 \\
\hline
\end{tabular}

$A V G$ Average, $S D$ standard deviation

the previous 10-days of precipitation and mole fractions of glycine, $\gamma$-Aba, and D-AA (Fig. 6; Table 3). A large decline in the mole percentage of $\gamma$-Aba during August 2012 corresponded to a very high precipitation event. Declines were less substantial in D-AA and were not observed in the mole percentage of glycine (Fig. 6).
Origins of DOM in groundwater

Lignin phenols $\left(\mathrm{TDLP}_{6}\right)$ were measured in two groundwater samples and two surface water samples, with much lower concentrations occurring in groundwater (Table 4). The acid to aldehyde ratios of vanillyl and syringyl phenols were not significantly 


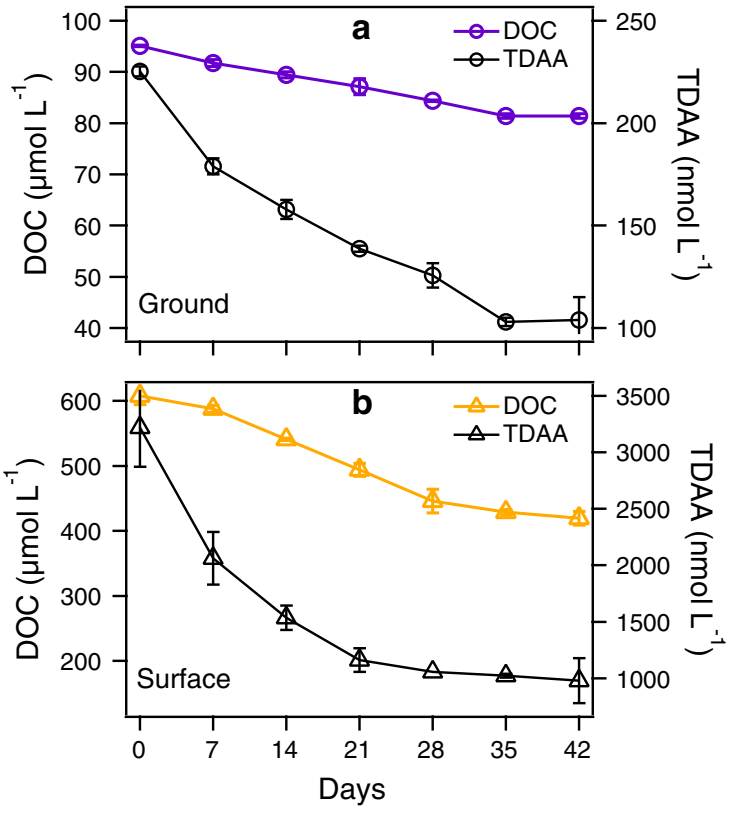

Fig. 2 Concentrations of dissolved organic carbon (DOC) and total dissolved amino acids (TDAA) during bioassay experiments with a ground and $\mathbf{b}$ surface waters. The two y-axes in each plot are scaled to be proportional. Error bars represent the standard deviations of three replicate incubations

different between surface water DOM and groundwater DOM $(p>0.1$, Table 4$)$. A significant relationship between $\mathrm{TDLP}_{6}$ concentrations and $a_{254}\left(R^{2}=0.882\right.$, $p=0.061, n=4)$ indicated $a_{254}$ is a useful proxy for lignin phenols in groundwater. SUVA 254 values in groundwater ranged from 1.42 to $1.77 \mathrm{~L} \mathrm{mgC}^{-1} \mathrm{~m}^{-1}$ and were about half of those $\left(2.33-3.19 \mathrm{~L} \mathrm{mgC}^{-1} \mathrm{~m}^{-1}\right)$ in surface water (Table 2). Examining the correlation between $\mathrm{SUVA}_{254}$ in groundwater and various periods (1-60 days) of integrated precipitation revealed the best relationship when using the previous 27-days of precipitation ( $r=0.600, p<0.005$; Fig. 7b). Likewise, concentrations of DOC were found to correlate best with the previous 27-days of precipitation (Table 3; Fig. 7a).

The yields of D-AA in freshly-produced bacterial DOM were used to calculate the bacterial contribution to DOC in groundwater (Table 5; Fig. 7c). Bacterial DOC in groundwater varied from 15 to $34 \%$ of the total DOC, with an average value of $20 \pm 4 \%$ (Fig. 7c). Percentages of bacterial DOC were not significantly correlated with precipitation (Fig. 7c; Table 3).
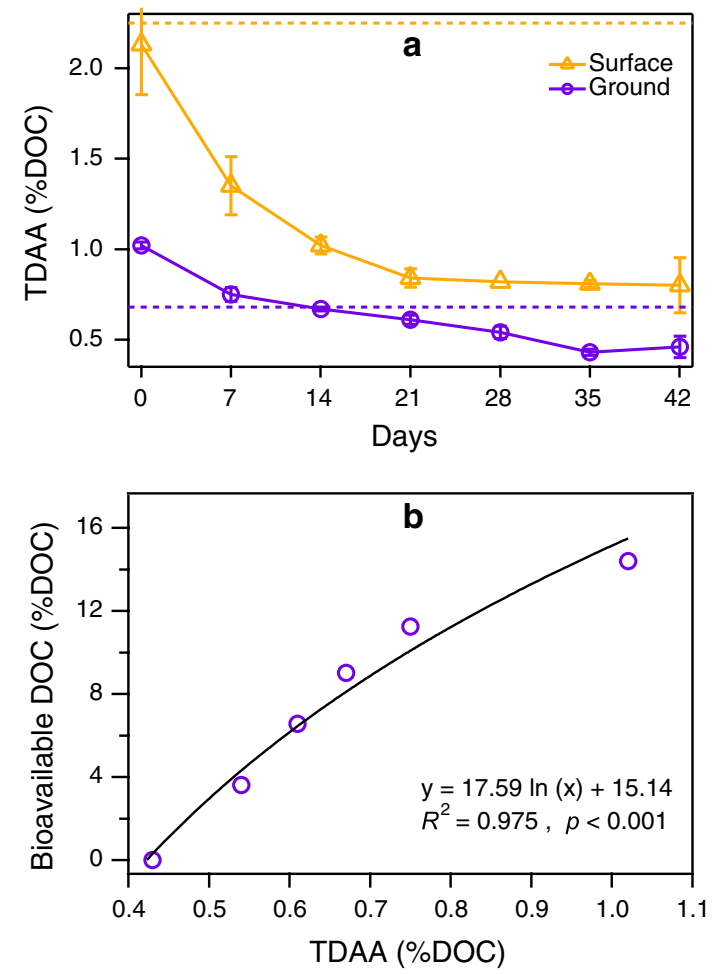

Fig. 3 a DOC-normalized yields of total dissolved amino acids (TDAA) during the unamended experiments with ground and surface waters. Error bars are the standard deviations. The purple and brown dashed lines represent the average values in the ground $(0.68 \%$ DOC, $n=24)$ and surface water samples (2.25\% DOC, $n=4)$, respectively. b Relationship between percentages of bioavailable DOC and TDAA yields

\section{Discussion}

The regional chromatography model

Surface water, soil, and groundwater are hydrologically linked as precipitation and other forms of surface water percolate through soils to the saturated zone (Sophocleous 2002). Selective interactions among water, organic matter, soil minerals, and microorganisms result in varying retention times of dissolved molecules during migration through the soil column, a phenomenon that has been described as regional chromatography (Hedges et al. 1986, 1994). Aluminosilicate clay minerals and metal oxides/hydroxides in soil selectively retain specific functional groups of organic molecules. Hydrophobic constituents are more strongly sorbed and more slowly transported through soils than hydrophilic molecules (Jardine et al. 
Fig. 4 Seasonal variations in percentages of bioavailable dissolved organic carbon (BDOC) and previous 10-days precipitation in groundwater

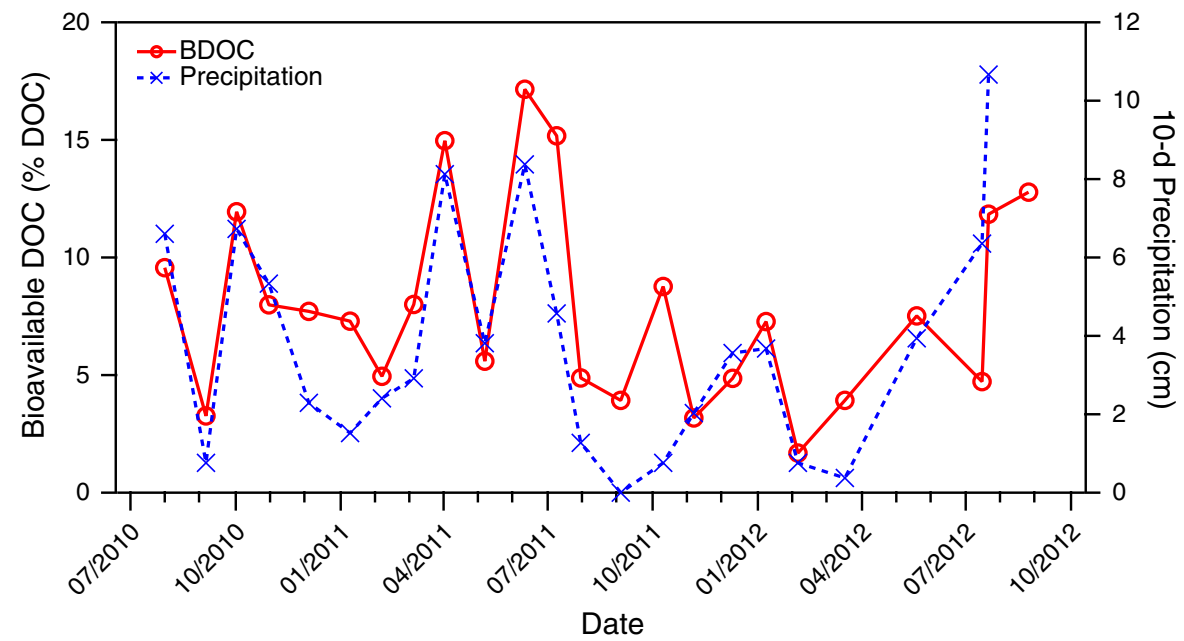

Table 3 Correlation matrix between precipitation (previous 10-days and 27-days) and DOM parameters in groundwater

\begin{tabular}{|c|c|c|c|c|c|c|c|c|c|}
\hline$(n=23)$ & $\begin{array}{l}\text { DOC } \\
\left(\mu \mathrm{mol} \mathrm{L}{ }^{-1}\right)\end{array}$ & $\begin{array}{l}a_{254} \\
\left(\mathrm{~m}^{-1}\right)\end{array}$ & $\begin{array}{l}a_{350} \\
\left(\mathrm{~m}^{-1}\right)\end{array}$ & $\begin{array}{l}\mathrm{SUVA}_{254} \\
\left(\mathrm{~L} \mathrm{mg}^{-1} \mathrm{~m}^{-1}\right)\end{array}$ & $\begin{array}{l}\text { BDOC } \\
(\% \text { DOC })\end{array}$ & $\begin{array}{l}\text { Gly } \\
(\mathrm{mol} \%)\end{array}$ & $\begin{array}{l}\gamma-\mathrm{Aba} \\
(\mathrm{mol} \%)\end{array}$ & $\begin{array}{l}\text { D-AA } \\
(\mathrm{mol} \%)^{*}\end{array}$ & $\begin{array}{l}\text { Bact. DOC } \\
(\% \text { DOC })\end{array}$ \\
\hline \multicolumn{10}{|l|}{ 10-days } \\
\hline$r$ & -0.098 & -0.089 & -0.092 & -0.003 & 0.735 & -0.614 & -0.406 & -0.648 & 0.268 \\
\hline$p$ & $>0.6$ & $>0.6$ & $>0.6$ & $>0.9$ & $<0.001$ & $<0.002$ & $<0.05$ & $<0.001$ & $>0.2$ \\
\hline \multicolumn{10}{|l|}{ 27-days } \\
\hline$r$ & 0.415 & 0.570 & 0.568 & 0.600 & 0.419 & -0.481 & -0.230 & -0.181 & 0.233 \\
\hline$p$ & $<0.05$ & $<0.05$ & $<0.05$ & $<0.005$ & $<0.05$ & $<0.05$ & $>0.2$ & $>0.4$ & $>0.2$ \\
\hline
\end{tabular}

$* \mathrm{D}-\mathrm{AA}(\%)=([\mathrm{D}-\mathrm{Asx}]+[\mathrm{D}-\mathrm{Glx}]+[\mathrm{D}-\mathrm{Ser}]+[\mathrm{D}-\mathrm{Ala}]) /([\mathrm{L}-\mathrm{Asx}]+[\mathrm{D}-\mathrm{Asx}]+[\mathrm{L}-\mathrm{Glx}]+[\mathrm{D}-\mathrm{Glx}]+[\mathrm{L}-\mathrm{Ser}]+[\mathrm{D}-\mathrm{Ser}]+[\mathrm{L}-\mathrm{Ala}]$ $+[\mathrm{D}-\mathrm{Ala}]) \times 100$

1989; Gu et al. 1995; Kaiser et al. 2004). Molecular hydrophobicity is primarily controlled by molecular size, polarity, charge, and bioavailability (Jardine et al. 1989; Gu et al. 1995; Arnarson and Keil, 2000; Theng 2012). Soil organic matter is subjected to degradation and remineralization by microbiota (Baker et al. 2000), which also release metabolites (Kawasaki and Benner 2006; Kaiser and Kalbitz, 2012; Hobara et al. 2014). Hydrology drives DOM transport through the soil column, and physicochemical and biological processes control retention time and shape the concentrations and compositions of colloidal and dissolved molecules during passage through the soil column (Fig. 8).

The long-term monitoring of precipitation and groundwater DOM demonstrated variable temporal patterns in the hydrological connectivity between surface and ground waters in the present study. The concentrations of DOC in groundwater were significantly correlated with the previous 27 -days of precipitation. This feature was observed throughout the 2-year sampling period, revealing a tight DOM connection between surface and ground waters. The measurements of plant-derived lignins in groundwater provide corroborated evidence for this statement. The continuity and strength of this hydrological connection can vary greatly with surface DOM concentrations, unsaturated zone sorption capacity, and the timing and intensity of precipitation (Datry et al. 2006). One example from this study is the uncoupling between DOC concentrations and precipitation during the last two sampling periods. A major precipitation event occurred at this time and it appeared to overwhelm the leaching capacity of soils resulting in a decrease in DOC concentrations in the groundwater. Baker et al. (2000) observed a similar variation in groundwater DOC concentration in response to the snowmelt. 

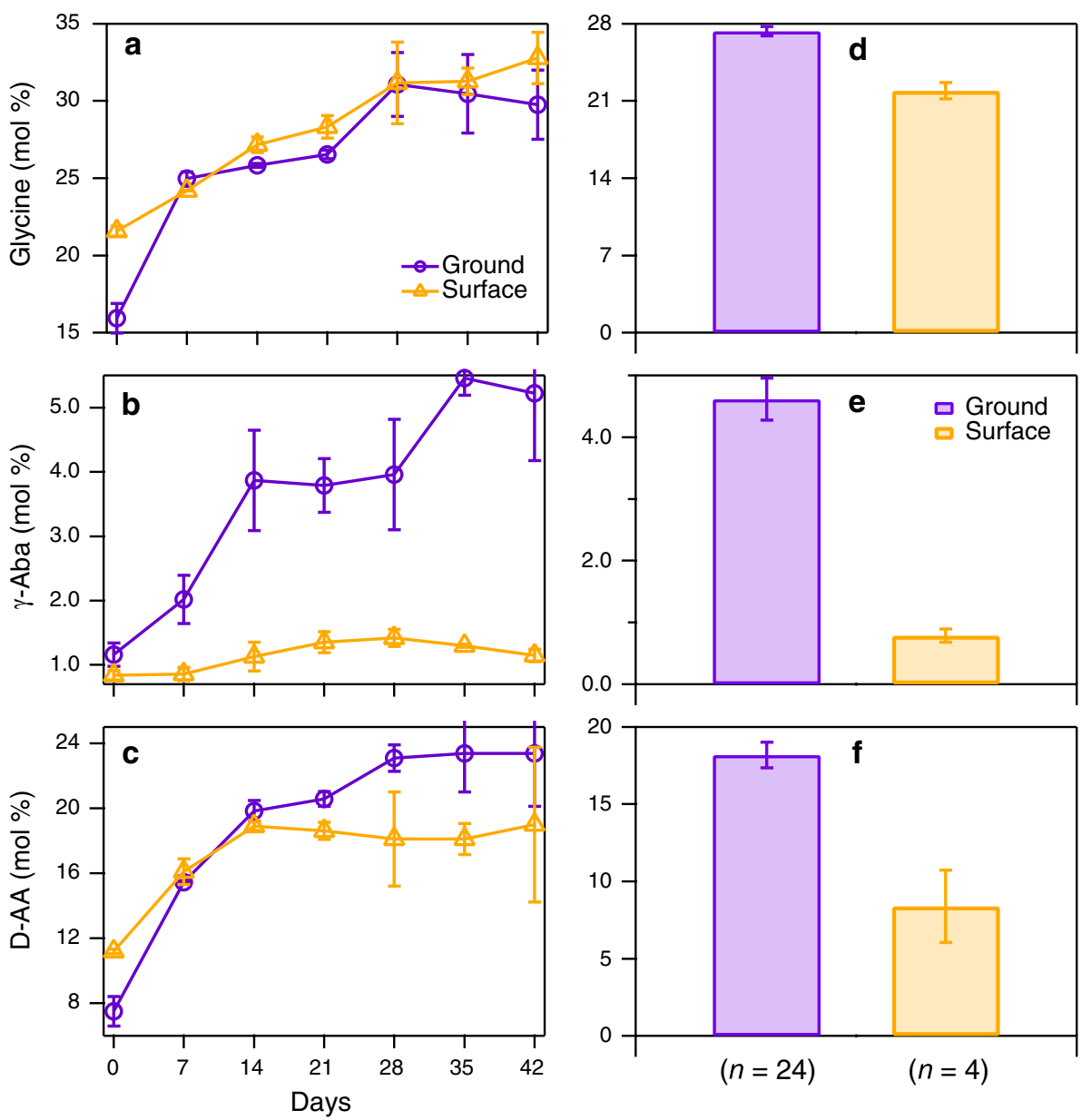

Fig. 5 Mole percentages of (a, d) glycine, $(\mathbf{b}, \mathbf{e}) \gamma$-aminobutyric acid $(\gamma$-Aba), and (c, $\mathbf{f})$ D-enantiomers of amino acids (D-AA) during the unamended experiments (left panel) and in the field samples (right panel)

The hydrological connections between surface and ground waters drives chromatographic migration of organic molecules through the soil columns described in the regional chromatography model. The concentrations of DOC were $\sim 10$-fold lower in groundwater than in surface water, apparently due to biotic and abiotic removal processes. Surface soils are important sources of DOC in groundwater (Baker et al. 2000; Aravena et al. 2004). Assuming DOC concentrations in surface waters are representative of those in surface soils, about $90 \%$ of surface-derived DOC is removed prior to reaching the saturated zone. The unamended bioassay experiments indicated $\sim 29 \%$ of surface water DOC was bioavailable, suggesting a large fraction of DOC was removed by abiotic processes (e.g., sorption) during infiltration (Kalbitz et al. 2000). The unsaturated zone in the present study contains a weathered clay layer (saprolite) where strong DOC sorption usually occurs (Jardine et al. 1989; Kalbitz et al. 2000). The relatively low concentrations of DOC in groundwater are consistent with pervious studies showing decreasing concentrations of DOC with soil depth (Pabich et al. 2001; Goldscheider et al. 2006; Inamdar et al. 2011).

Linking groundwater DOM with surface precipitation revealed differential transport of DOM constituents through soils. The bioavailable fraction of DOC and other amino acid parameters were most strongly correlated with the previous 10-days of precipitation, whereas DOC and the fraction of plant-derived DOM, as indicated by $\mathrm{SUVA}_{254}$, were correlated with a longer precipitation period (27-days). These patterns are indicative of regional chromatography, which describes the selective removal and differential 
Fig. 6 Seasonal variations in mole percentages of a glycine, $\mathbf{b} \gamma$-aminobutyric acid ( $\gamma$-Aba), and $\mathbf{c} \mathrm{D}^{-}$ enantiomers of amino acids (D-AA). Blue dashed lines represent previous 10-days precipitation
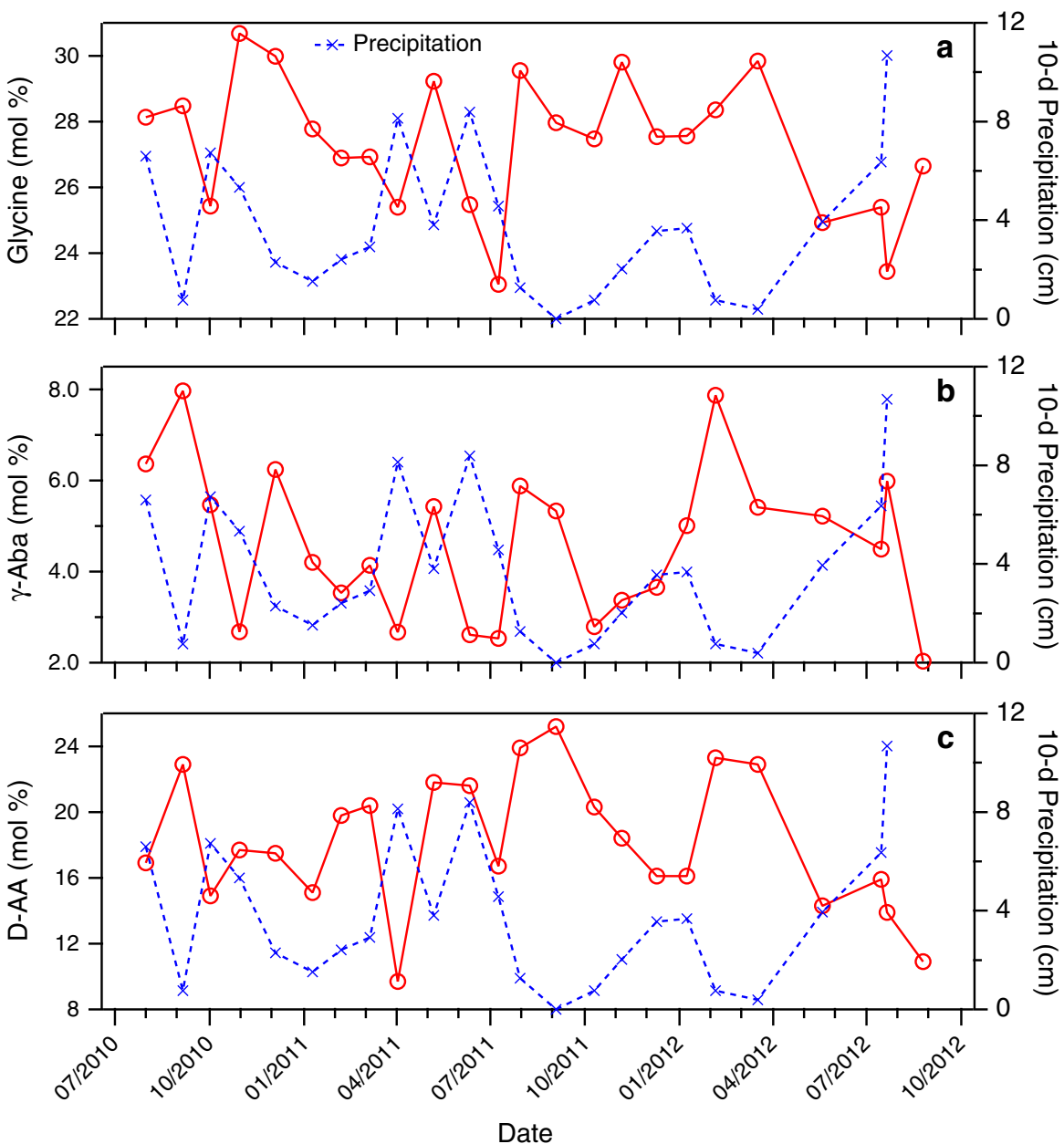

Table 4 Lignin phenols in ground and surface waters*

\begin{tabular}{lllllllllll}
\hline & Date & $\begin{array}{l}\mathrm{V} \\
\left.(\mathrm{nmol} \mathrm{L})^{-1}\right)\end{array}$ & $\begin{array}{l}\mathrm{S} \\
\left.(\mathrm{nmol} \mathrm{L})^{-1}\right)\end{array}$ & $\begin{array}{l}\mathrm{C} \\
\left.(\mathrm{nmol} \mathrm{L})^{-1}\right)\end{array}$ & $\mathrm{S} / \mathrm{V}$ & $\mathrm{C} / \mathrm{V}$ & $(\mathrm{Ad} / \mathrm{Al})_{\mathrm{S}}$ & $(\mathrm{Ad} / \mathrm{Al})_{\mathrm{V}}$ & $\begin{array}{l}\mathrm{TDLP}_{6} \\
\left.(\mathrm{nmol} \mathrm{L})^{-1}\right)\end{array}$ & $(\% \mathrm{DOC})$ \\
\hline Groundwater & $5 / 19 / 12$ & 1.12 & 0.51 & 0.17 & 0.46 & 0.15 & 0.92 & 0.85 & 1.6 & 0.015 \\
& $7 / 21 / 12$ & 1.74 & 0.63 & 0.17 & 0.36 & 0.10 & 0.69 & 0.66 & 2.4 & 0.023 \\
Surface water & $5 / 19 / 12$ & 102 & 40 & 10 & 0.38 & 0.10 & 0.71 & 0.83 & 141 & 0.17 \\
& $7 / 20 / 12$ & 732 & 438 & 62 & 0.60 & 0.08 & 0.75 & 0.95 & 1170 & 0.65 \\
\hline
\end{tabular}

$* \mathrm{~V}=\mathrm{VAL}+\mathrm{VON}+\mathrm{VAD}, \mathrm{S}=\mathrm{SAL}+\mathrm{SON}+\mathrm{SAD}, \mathrm{C}=\mathrm{CAD}+\mathrm{FAD} . \mathrm{S} / \mathrm{V}=$ molar ratio of $\mathrm{S}$ to $\mathrm{V} ; \mathrm{C} / \mathrm{V}=\mathrm{molar}$ ratio of $\mathrm{C}$ to $\mathrm{V}$. $(\mathrm{Ad} / \mathrm{Al})_{\mathrm{S}}=$ molar ratio of $\mathrm{SAD}$ to $\mathrm{SAL} ;(\mathrm{Ad} / \mathrm{Al})_{\mathrm{V}}=$ molar ratio of $\mathrm{VAD}$ to VAL. Abbreviations were provided in the Methods

retention of DOM constituents during transport from surface to ground waters. Molecular properties (e.g., size, hydrophobicity, and charge) affect sorption processes, with hydrophobic macromolecules, such as lignins, being preferentially sorbed onto minerals and retained for longer periods of time during passage through the soil column (Kaiser et al. 2004; Inamdar et al. 2012). Some bioavailable components of DOM, such as amino acids and carbohydrates, are highly mobile and eluted rapidly to the saturated zone (Kaiser et al. 2004). Fungi and bacteria are abundant in soils, exposing DOM to a diverse array of enzymes that 
Fig. 7 Seasonal variations in a concentrations of dissolved organic carbon (DOC), b specific UV absorbance at $254 \mathrm{~nm}$ $\left(\mathrm{SUVA}_{254}\right)$, and c percentages of bacterial DOC. Blue dashed lines represent precipitation of previous 27-days (a, b) and 10-days (c)
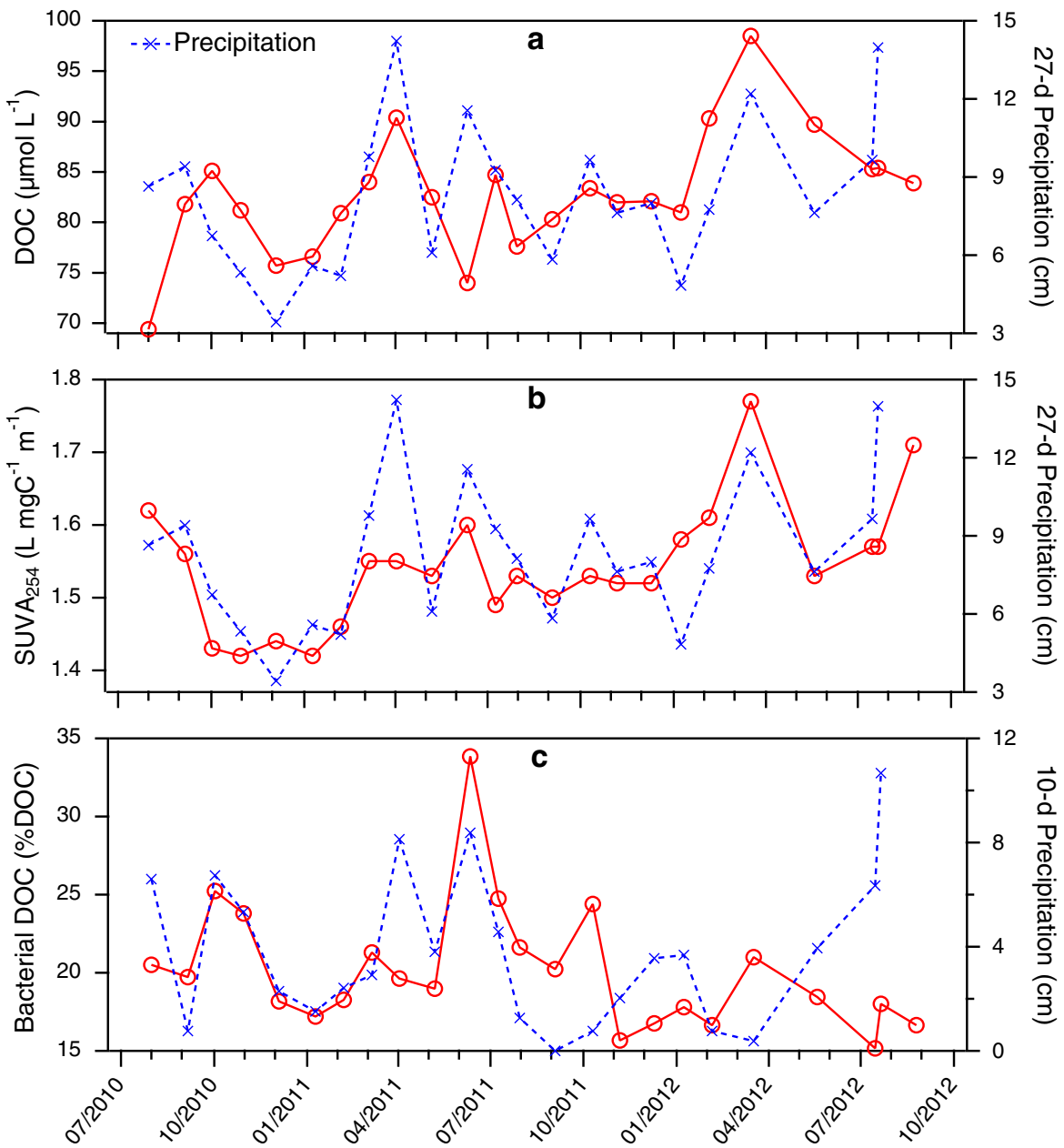

Date

Table 5 Yields of D-amino acids in freshly-produced bacterial DOM

\begin{tabular}{llll}
$\begin{array}{l}\text { D-Asx } \\
\left(\mathrm{nmol} \mathrm{mgC} \mathrm{mg}^{-1}\right)\end{array}$ & D-Glx $\left(\mathrm{nmol} \mathrm{mgC} \mathrm{me}^{-1}\right)$ & D-Ser $\left(\mathrm{nmol} \mathrm{mC}^{-1}\right)$ & D-Ala $\left(\mathrm{nmol} \mathrm{mgC}^{-1}\right)$ \\
$5.8 \pm 3.3$ & $15 \pm 7.8$ & $6.6 \pm 3.8$ & $24 \pm 11$ \\
\hline
\end{tabular}

Bacterial DOM

he average \pm standard deviation

selectively alter and remineralize components during their percolation through the soil (Kalbitz et al. 2000).

Low concentrations of lignin-derived phenols were measured in groundwater samples, indicating substantial removal of these plant-derived molecules during transport through the soil. The DOC-normalized absorbance at $254 \mathrm{~nm}, \mathrm{SUVA}_{254}$, has been used to trace the lignin component of DOM in rivers (Spencer et al. 2010) and is used in this study for tracing the fraction of plant-derived DOM in groundwater. Significantly lower $\mathrm{SUVA}_{254}$ values in groundwater than in surface water corroborate the relatively low concentrations of plant-derived chromophoric DOM in groundwater. The $\mathrm{SUVA}_{254}$ values reported in this study fall within the range of values measured in groundwater and in rivers dominated by groundwater inputs (Spencer et al. 2008; Chapelle et al. 2011; Inamdar 2011; Spencer et al. 2012). The $S_{275-295}$ values in groundwater were significantly higher than those in surface waters (Shen et al. 


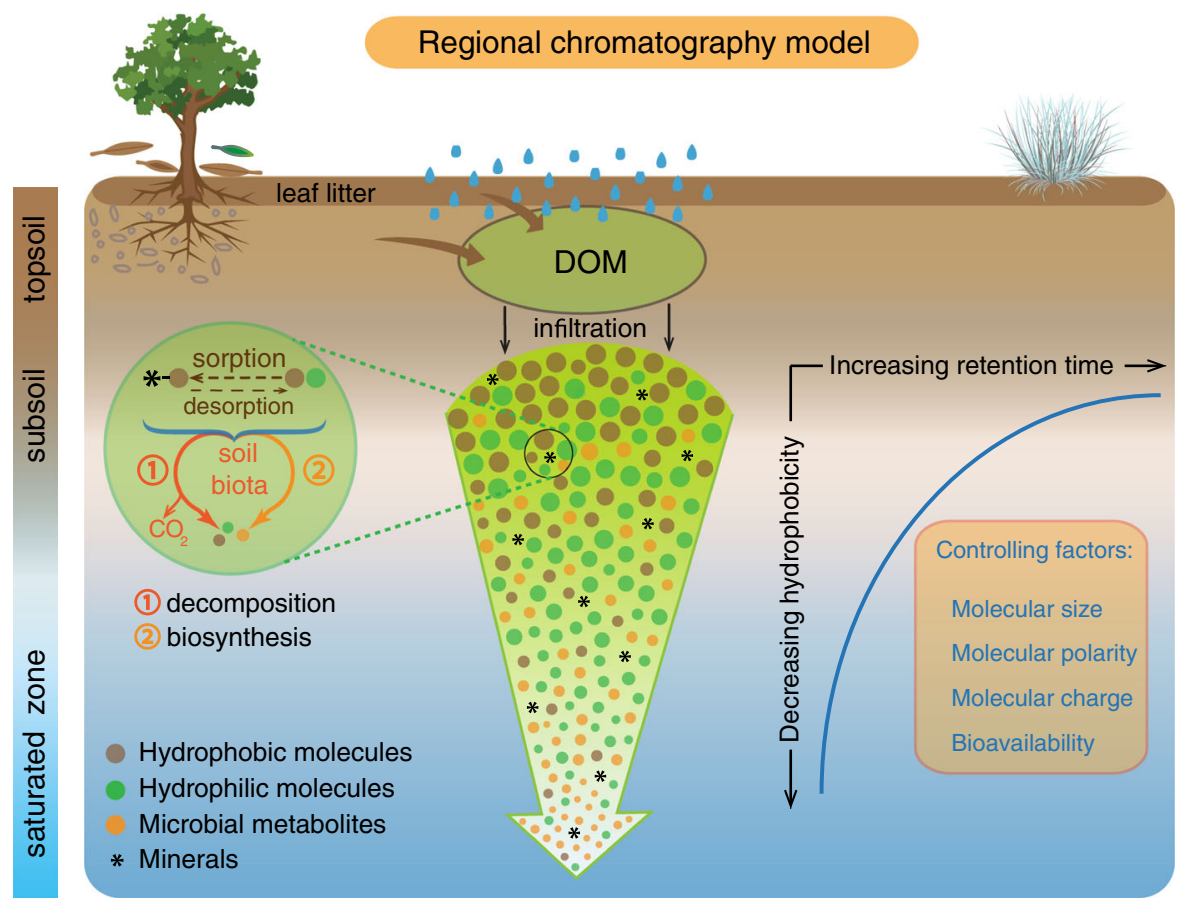

Fig. 8 Regional Chromatography Model-precipitation and surface water leaches dissolved organic matter (DOM) from vegetation and plant litter and percolates through the soil column to the saturated zone. The concentration, composition, and bioavailability of DOM are altered during transport through the soil column by various physicochemical and biological processes, including sorption, desorption, biodegradation and biosynthesis. Hydrophobic molecules are preferentially

2012b; this study), indicating the average molecular weight of DOM in groundwater is lower than that in surface water (Helms et al. 2008). Microbial degradation and sorption onto minerals in the unsaturated zone are likely responsible for the removal of lignin and other components of chromophoric DOM (Kaiser et al. 2004; Inamdar et al. 2011; Ward et al. 2013).

\section{DOM bioavailability in groundwater}

The bioavailability of DOC is commonly determined using bioassay experiments, and in the present study this approach was used to develop a molecular indicator of BDOC that could be measured in water samples without conducting the time consuming bioassay experiments during each collection of groundwater samples (Benner 2003; Davis and Benner 2007). The fraction of BDOC in groundwater was estimated using TDAA yields based on the robust relationship between these variables during bioassay partitioned onto soil minerals and have a longer retention time in soils than hydrophilic molecules. The hydrophobicity and retention time of colloids and dissolved molecules in soils are controlled by their size, polarity, charge, and bioavailability. Bioavailable DOM is subjected to microbial decomposition, resulting in a reduction in size and molecular weight. Novel molecules are synthesized by soil microbes, and some of these metabolites enter the DOM reservoir in groundwater

experiments. We assumed that no DOC was bioavailable when TDAA yields were below $0.43 \%$ DOC, the lowest value observed during the 42-days bioassay experiments. This threshold value is at the lower end of the range of values (0.4-0.8\% DOC) observed in deep ocean water, where BDOC is in extremely low concentrations (Davis and Benner 2005; Kaiser and Benner 2009). In addition, the range of TDAA yields observed in groundwater fell within the range (23 out of $24 ; 96 \%$ ) observed during the bioassay experiments, further validating the quantitative approach used in this study.

An average of $8 \pm 4 \%$ of the DOC in groundwater was bioavailable in this study, which is similar to estimates in other studies using bioassay measurements (Grøn et al. 1992; Romaní et al. 2006; Chomycia et al. 2008). The TDAA yields measured in 47 groundwater samples from California, Georgia, South Carolina, and New Jersey were mostly below $1 \%$ DOC, indicating similarly low BDOC in groundwater from a wide range 
of systems (Chapelle et al. 2009, 2011). In comparison, substantially higher percentages of BDOC were measured in surface water ( $29 \pm 1 \%$; this study), which is consistent when compared to average literature values for streams (11-27\%), lakes (14\%), rivers (19\%), and seawater (19\%) (Qualls and Haines 1992; Søndergaard and Middelboe 1995; Volk et al. 1997; Stutter et al. 2013). The percentages of BDOC reported in coastal estuaries were quite variable $(8-29 \%)$ but mostly higher than those in groundwater (Moran and Hodson 1999; Raymond and Bauer 2000; Lønborg et al. 2009; Lønborg and Søndergaard 2009). Differences among reported estimates could be due to variable incubation times and estimation methods (Sondergaard and Middelboe 1995). Nevertheless, BDOC in groundwater is consistently low in comparison with values for other aquatic systems.

The litter layer is an important source of DOM, and it appears leachates from the litter layer contribute to the BDOC in groundwater. The correlation between BDOC and recharge to the aquifer, as indicated by the previous 10-days of precipitation, indicates the rapid transport of BDOC through the soil. Substantial remineralization of BDOC occurs in the upper soil horizons, resulting in the relatively low concentrations of BDOC in groundwater. This interpretation is consistent with previous observations in sand and gravel aquifers that show concentrations of DOC decrease rapidly with increasing thickness of the unsaturated zone (Pabich et al. 2001).

Amino acid-based indicators revealed that DOM in groundwater is diagenetically altered. Glycine, $\gamma$ aminobutyric acid, and D-AA have been used as diagenetic indicators of sedimentary organic matter, estuarine and marine DOM (Cowie and Hedges 1994; Jørgensen et al. 1999; Kaiser and Benner 2009). Incubation experiments in this study clearly demonstrated an enrichment of the three indicators during biodegradation, and the mole percentages of these molecular indicators were significantly higher in groundwater than those in surface water. These high values are consistent with the low BDOC, low TDAA yields, low dissolved oxygen concentrations (avg.: $44 \pm 19 \mu \mathrm{mol} \mathrm{L}^{-1}$ ), and low molecular weight of DOM, indicating DOM in groundwater has undergone extensive microbial alteration. Values of the three indicators were similar to those found in deep Pacific Ocean DOM, which is highly altered and resistant to biodegradation (Kaiser and Benner 2008, 2009).
The low bioreactivity of DOM in groundwater appears to be an integrated result of biotic and abiotic processes in soils and groundwater. The DOM collected from surface and ground waters showed distinct compositions during the bioassay incubations, suggesting microbial degradation of surface DOM in situ is not the only process shaping the composition of groundwater DOM. Other alteration processes must be active as surface DOM infiltrates into the groundwater. Hydrologic mixing can influence DOC concentrations in groundwater (Foulquier et al. 2010), but mixing does not appear to be the major factor controlling the composition of DOM in groundwater. Sorption alters the composition of DOM by preferentially removing hydrophobic macromolecules, but it has less influence on bioavailable components (e.g., amino acids and carbohydrates) (Jardine et al. 1989; Kaiser et al. 2004; Inamdar et al. 2012). The extremely low TDAA yields in groundwater indicate extensive microbial alteration of DOM in groundwater (Goldscheider et al. 2006). Biodegradation experiments revealed consistently lower TDAA yields and higher mole percentages of $\gamma$-Aba in groundwater DOM than in surface water DOM, implying microbial community structure could also play a role in shaping the composition and bioreactivity of DOM.

\section{Bacterial contributions to DOM in groundwater}

Several studies have demonstrated the presence of biomarkers derived from bacteria and fungi in soil organic matter (Guggenberger et al. 1999; Amelung et al. 2006; Hobara et al. 2014), but the contributions of these microbes to DOM in groundwater have not been investigated. In the present study, the yields of D-AA indicated $15-34 \%$ of the DOC in groundwater (avg.: $20 \pm 6 \%$ ) was of bacterial origin. These relatively high values are consistent with the low bioreactivity of DOM in groundwater, revealing the important role of soil bacteria in producing, as well as consuming, DOM (Benner 2010). The average bacterial contribution to DOC in groundwater is comparable to that in the ocean ( $\sim 25 \%$ ) (Kaiser and Benner 2008) and is somewhat lower than that estimated in streams $(32 \pm 10 \%$; this study) and lake water (30-50 \% DOC; Kawasaki et al. 2013). The weak correlation between precipitation and DOC of bacterial origin indicates other factors, such as bioavailable substrates and groundwater residence time, regulate the contributions of bacterial to DOC in 
groundwater. The bacterial DOC in groundwater could be derived from surface water, soils in the unsaturated zone, and in situ production in groundwater.

Overall, DOM in groundwater is a mixture of components derived from various sources and altered by multiple processes, making it difficult to predict the composition and bioreactivity of DOM solely from bulk DOM analyses (Chapelle et al. 2009; Shen et al. 2012a).The regional chromatography model is presented as a conceptual framework for understanding the sources and processes influencing the properties of DOM during its transport from the surface litter layer to groundwater. Additional studies of water transit times and pathways through soils would provide further insights about the processes shaping the concentration, composition, and bioavailability of DOM in groundwater. A fundamental understanding of these processes is needed for wise management of groundwater resources and the implementation of bioremediation strategies for contaminated groundwater.

Acknowledgments We thank Cedric Fichot for the measurements of lignin phenols and Jessica Asirwatham for assistance with the bioassay experiments. We thank the reviewers for their comments and suggestions. This research was supported by the National Water Quality Assessment (NAWQA) and Toxic Substances Hydrology programs of the U.S. Geological Survey.

Open Access This article is distributed under the terms of the Creative Commons Attribution License which permits any use, distribution, and reproduction in any medium, provided the original author(s) and the source are credited.

\section{References}

Amelung W, Zhang X, Flach KW (2006) Amino acids in grassland soils: climatic effects on concentrations and chirality. Geoderma 130:207-217

Aravena R, Wassenaar LI, Spiker EC (2004) Chemical and carbon isotopic composition of dissolved organic carbon in a regional confined methanogenic aquifer. Isotopes Environ Health Stud 40(2):103-114

Arnarson TS, Keil RG (2000) Mechanisms of pore water organic matter adsorption to montmorillonite. Mar Chem 71(3):309-320

Baker MA, Valett HM, Dahm CN (2000) Organic carbon supply and metabolism in a shallow groundwater ecosystem. Ecology 81(11):3133-3148

Barcelona MJ (1984) TOC determinations in ground water. Groundwater 22(1):18-24

Benner R (2003) Molecular indicators of the bioavailability of dissolved organic matter. In: Findlay S, Sinsabaugh R (eds)
Aquatic ecosystems: interactivity of dissolved organic matter. Elsevier, San Diego, pp 121-137

Benner R (2010) Biosequestration of carbon by heterotrophic microorganisms. Nat Rev Microbiol 9:75

Benner R, Strom M (1993) A critical evaluation of the analytical blank associated with DOC measurements by high-temperature catalytic oxidation. Mar Chem 41:153-160

Benner R, Louchouarn P, Amon RMW (2005) Terrigenous dissolved organic matter in the Arctic Ocean and its transport to surface and deep waters of the North Atlantic. Glob Biogeochem Cycles 19 (2):GB2025. doi:10.1029/ 2004GB002398

Chapelle FH, Bradley PM, Goode DJ, Tiedeman C, Lacombe PJ, Kaiser K, Benner R (2009) Biochemical indicators for the bioavailability of organic carbon in ground water. Groundwater 47(1):108-121

Chapelle FH, Bradley PM, McMahon PB, Kaiser K, Benner R (2011) Dissolved oxygen as an indicator of bioavailable dissolved organic carbon in groundwater. Groundwater 50(2):230-241

Chiou CT, Malcolm RL, Brinton TI, Kile DE (1986) Water solubility enhancement of some organic pollutants and pesticides by dissolved humic and fulvic acids. Environ Sci Technol 20(5):502-508

Chomycia JC, Hernes PJ, Harter T, Bergamaschi BA (2008) Land management impacts on dairy-derived dissolved organic carbon in ground water. J Environ Qual 37(2):333-343

Cowie GL, Hedges JI (1994) Biochemical indicators of diagenetic alteration in natural organic-matter mixtures. Nature 369(6478):304-307

Cunningham WL, Geiger LH, Karavitis GA (2007) U.S. Geological Survey Ground-Water Climate Response Network. Fact Sheet 2007-3003. U.S. Department of the Interior, U.S. Geological Survey

Datry T, Malard F, Gibert J (2006) Effects of artificial storm water infiltration on urban groundwater ecosystems. In: Tellam JH, Rivett MO, Israfilov RG, Herringshaw LG (eds) Urban groundwater management and sustainability. Springer, Netherlands, pp 331-345

Davis J, Benner R (2005) Seasonal trends in the abundance, composition and bioavailability of particulate and dissolved organic matter in the Chukchi/Beaufort Seas and western Canada Basin. Deep-Sea Res Part II Top Stud Oceanogr 52:3396-3410

Davis J, Benner R (2007) Quantitative estimates of labile and semilabile dissolved organic carbon in the western Arctic Ocean: a molecular approach. Limnol Oceanogr 52(6):2434-2444

Davis J, Kaiser K, Benner R (2009) Amino acid and amino sugar yields and compositions as indicators of dissolved organic matter diagenesis. Org Geochem 40(3):343-352

Foulquier A, Malard F, Mermillod-Blondin F, Datry T, Simon L, Montuelle B, Gibert J (2010) Vertical change in dissolved organic carbon and oxygen at the water table region of an aquifer recharged with storm water: biological uptake or mixing? Biogeochemistry 99:31-47

Goldscheider N, Hunkeler D, Rossi P (2006) Review: microbial biocenoses in pristine aquifers and an assessment of investigative methods. Hydrogeol J 14(6):926-941

Grøn C, Tørsløv J, Albrechtsen H-J, Jensen HM (1992) Biodegradability of dissolved organic carbon in groundwater from an unconfined aquifer. Sci Total Environ 118:241-251 
Gu B, Schmitt J, Chen Z, Liang L, McCarthy JF (1995) Adsorption and desorption of different organic matter fractions on iron oxide. Geochim Cosmochim Acta 59(2):219-229

Guggenberger G, Frey SD, Six J, Paustian K, Elliott ET (1999) Bacterial and fungal cell-wall residues in conventional and notillage agroecosystems. Soil Sci Soc Am J 63(5):1188-1198

Hedges JI, Ertel JR, Quay PD, Grootes PM, Richey JE, Devol AH, Farwell GW, Schmidt FW, Salati E (1986) Organic carbon-14 in the Amazon River system. Science 231(4742): $1129-1131$

Hedges JI, Cowie GL, Richey JE, Quay PD, Benner R, Strom M, Forsberg BR (1994) Origins and processing of organicmatter in the Amazon River as indicated by carbohydrates and amino-acid. Limnol Oceanogr 39(4):743-761

Helms JR, Stubbins A, Ritchie JD, Minor EC, Kieber DJ, Mopper K (2008) Absorption spectral slopes and slope ratios as indicators of molecular weight, source, and photobleaching of chromophoric dissolved organic matter. Limnol Oceanogr 53(3):955-969

Hendriksen HV, Larsen S, Ahring BK (1992) Influence of a supplemental carbon source on anaerobic dechlorination of pentachlorophenol in granular sludge. Appl Environ Microbiol 58(1):365-370

Hibbard JP, Stoddard EF, Secor DT, Dennis AJ (2002) The Carolina Zone: overview of Neoproterozoic to Early Paleozoic peri-Gondwanan terranes along the eastern flank of the southern Appalachians. Earth-Sci Rev 57(3):299-339

Hobara S, Osono T, Hirose D, Noro K, Hirota M, Benner R (2014) The roles of microorganisms in litter decomposition and soil formation. Biogeochemistry 118:471-486

Inamdar S (2011) The use of geochemical mixing models to derive runoff sources and hydrologic flow paths. In: Levia DF, Carlyle-Moses D, Tanaka T (eds) Forest hydrology and biogeochemistry. Springer, Netherlands, pp 163-183

Inamdar S, Singh S, Dutta S, Levia D, Mitchell M, Scott D, Bais $\mathrm{H}$, McHale P (2011) Fluorescence characteristics and sources of dissolved organic matter for stream water during storm events in a forested mid-Atlantic watershed. J Geophys Res 116:G03043. doi:10.1029/2011JG001735

Inamdar S, Finger N, Singh S, Mitchell M, Levia D, Bais H, Scott D, McHale P (2012) Dissolved organic matter (DOM) concentration and quality in a forested midAtlantic watershed, USA. Biogeochemistry 108:55-76

Jardine P, McCarthy J, Weber N (1989) Mechanisms of dissolved organic carbon adsorption on soil. Soil Sci Soc Am J 53(5):1378-1385

Jørgensen NO, Tranvik LJ, Berg GM (1999) Occurrence and bacterial cycling of dissolved nitrogen in the Gulf of Riga, the Baltic Sea. Mar Ecol Prog Ser 191:1-18

Kaiser K, Benner R (2005) Hydrolysis-induced racemization of amino acids. Limnol Oceanogr-Methods 3:318-325

Kaiser K, Benner R (2008) Major bacterial contribution to the ocean reservoir of detrital organic carbon and nitrogen. Limnol Oceanogr 53(1):99-112

Kaiser K, Benner R (2009) Biochemical composition and size distribution of organic matter at the Pacific and Atlantic time-series stations. Mar Chem 113:63-77

Kaiser K, Benner R (2012) Characterization of lignin by gas chromatography and mass spectrometry using a simplified $\mathrm{CuO}$ oxidation method. Anal Chem 84(1):459-464
Kaiser K, Kalbitz K (2012) Cycling downwards-dissolved organic matter in soils. Soil Biol Biochem 52:29-32

Kaiser K, Guggenberger G, Haumaier L (2004) Changes in dissolved lignin-derived phenols, neutral sugars, uronic acids, and amino sugars with depth in forested Haplic Arenosols and Rendzic Leptosols. Biogeochemistry 70(1):135-151

Kalbitz K, Solinger S, Park JH, Michalzik B, Matzner E (2000) Controls on the dynamics of dissolved organic matter in soils: a review. Soil Sci 165(4):277-304

Kawasaki N, Benner R (2006) Bacterial release of dissolved organic matter during cell growth and decline: molecular origin and composition. Limnol Oceanogr 51:2170-2180

Kawasaki N, Komatsu K, Kohzu A, Tomioka N, Shinohara R, Satou T, Watanabe FN, Tada Y, Hamasaki K, Kushairi M (2013) Bacterial contribution to dissolved organic matter in eutrophic Lake Kasumigaura, Japan. Appl Environ Microbiol 79(23):7160-7168

Leenheer J, Malcolm R, McKinley P, Eccles L (1974) Occurrence of dissolved organic carbon in selected ground-water samples in the United States. J Res US Geol Surv 2:361-369

Lønborg C, Søndergaard M (2009) Microbial availability and degradation of dissolved organic carbon and nitrogen in two coastal areas. Est Coast Shelf Sci 81(4):513-520

Lønborg C, Davidson K, Álvarez-Salgado XA, Miller AEJ (2009) Bioavailability and bacterial degradation rates of dissolved organic matter in a temperate coastal area during an annual cycle. Mar Chem 113(3):219-226

Louchouarn P, Opsahl S, Benner R (2000) Isolation and quantification of dissolved lignin from natural waters using solidphase extraction and GC/MS. Anal Chem 72(13):2780-2787

McCarthy MD, Hedges JI, Benner R (1998) Major bacterial contribution to marine dissolved organic nitrogen. Science 281(5374):231-234

McCarty PL (1997) Breathing with chlorinated solvents. Science 276(5318):1521-1522

Meyers-Schulte KJ, Hedges JI (1986) Molecular evidence for a terrestrial component of organic matter dissolved in ocean water. Nature 321(6065):61-63

Moran MA, Hodson RE (1999) Bacterial production on humic and nonhumic components of dissolved organic carbon. Limnol Oceanogr 35(8):1744-1756

Ogawa H, Amagai Y, Koike I, Kaiser K, Benner R (2001) Production of refractory dissolved organic matter by bacteria. Science 292(5518):917-920

Opsahl S, Benner R (1997) Distribution and cycling of terrigenous dissolved organic matter in the ocean. Nature 386(6624):480-482

Pabich WJ, Valiela I, Hemond HF (2001) Relationship between DOC concentration and vadose zone thickness and depth below water table in groundwater of Cape Cod, USA. Biogeochemistry 55(3):247-268

Peter S, Shen Y, Kaiser K, Benner R, Durisch-Kaiser E (2012) Bioavailability and diagenetic state of dissolved organic matter in riparian groundwater. $\mathrm{J}$ Geophys Res 117:G04006. doi:10.1029/2012JG002072

Porcella DB et al (1980) Bioassay methods for aquatic organisms. In: Greenberg AE, Connors JJ, Jenkins D (eds) Standard methods for the examination of water and wastewater, 15th edn. American Public Health Association, Washington, D.C., pp 615-649 
Qualls RG, Haines BL (1992) Biodegradability of dissolved organic matter in forest throughfall, soil solution, and stream water. Soil Sci Soc Am J 56(2):578-586

Raymond PA, Bauer JE (2000) Bacterial consumption of DOC during transport through a temperate estuary. Aquat Microb Ecol 22(1):1-12

Romaní AM, Vázquez E, Butturini A (2006) Microbial availability and size fractionation of dissolved organic carbon after drought in an intermittent stream: biogeochemical link across the stream-riparian interface. Microb Ecol 52(3):501-512

Routh J, Grossman EL, Murphy EM, Benner R (2001) Characterization and origin of dissolved organic carbon in Yegua ground water in Brazos County, Texas. Groundwater 39(5):760-767

Shen Y, Fichot C, Benner R (2012a) Dissolved organic matter composition and bioavailability reflect ecosystem productivity in the Western Arctic Ocean. Biogeosciences 9:4993-5005

Shen Y, Fichot CG, Benner R (2012b) Floodplain influence on dissolved organic matter composition and export from the Mississippi-Atchafalaya River system to the Gulf of Mexico. Limnol Oceanogr 57(4):1149-1160

Singer PC (1994) Control of disinfection by-products in drinking water. J Environ Eng 120(4):727-744

Søndergaard M, Middelboe M (1995) A cross-system analysis of labile dissolved organic carbon. Mar Ecol Prog Ser 118(1):283-294

Sophocleous M (2002) Interactions between groundwater and surface water: the state of the science. Hydrogeol $\mathrm{J}$ 10(1):52-67

Spencer RGM, Aiken GR, Wickland KP, Striegl RG, Hernes PJ (2008) Seasonal and spatial variability in dissolved organic matter quantity and composition from the Yukon River basin, Alaska. Glob Biogeochem Cycles 22 (4):GB4002. doi:10.1029/2008gb003231
Spencer RGM, Hernes PJ, Ruf R, Baker A, Dyda RY, Stubbins A, Six J (2010) Temporal controls on dissolved organic matter and lignin biogeochemistry in a pristine tropical river, Democratic Republic of Congo. J Geophys ResBiogeosciences 115:G03013. doi:10.1029/2009jg001180

Spencer RG, Butler KD, Aiken GR (2012) Dissolved organic carbon and chromophoric dissolved organic matter properties of rivers in the USA. J Geophys Res 117:G03001. doi:10.1029/2011JG001928

Stutter M, Richards S, Dawson J (2013) Biodegradability of natural dissolved organic matter collected from a UK moorland stream. Water Res 47:1169-1180

Theng BKG (2012) Formation and properties of clay-polymer complexes. Elsevier, Amsterdam

Thurman EM (1985) Organic geochemistry of natural waters. Martinus Nijhoff/Dr W. Junk Publishers, Dordrecht, The Netherlands

Volk CJ, Volk CB, Kaplan LA (1997) Chemical composition of biodegradable dissolved organic matter in streamwater. Limnol Oceanogr 42(1):39-44

Vroblesky DA, Casey CC, Lowery MA (2006) Influence of inwell convection on well sampling. Sci Investig Rep 2006-5247. U.S. Department of the Interior, U.S. Geological Survey

Ward ND, Keil RG, Medeiros PM, Brito DC, Cunha AC, Dittmar T, Yager PL, Krusche AV, Richey JE (2013) Degradation of terrestrially derived macromolecules in the Amazon River. Nat Geosci 6(7):530-533

Weishaar JL, Aiken GR, Bergamaschi BA, Fram MS, Fujii R, Mopper K (2003) Evaluation of specific ultraviolet absorbance as an indicator of the chemical composition and reactivity of dissolved organic carbon. Environ Sci Technol 37(20):4702-4708 